\title{
Exchange of knowledge about fires and burnings in search of integrated fire management in the IT Araribóia/MA and surroundings
}

\author{
Marques, A.R $R^{1^{*}}$ Martins, R. $C^{l}$ e Amorim, A. $B^{l}$. \\ ${ }^{1}$ Instituto Brasileiro de Meio Ambiente e Recursos Naturais Renováveis (Ibama), SUPES/Maranhão, Brasil \\ *E-mail para contato: anclaros@yahoo.com.br
}

\begin{abstract}
This work brings the experience of the Indigenous Land (IT) Araribóia and surrounding municipalities, as a way to minimize the environmental impacts caused by the high rate of fires that this area has presented, threatening the conservation of the Amazon rainforest and the survival of the indigenous people. Guajajara and the isolated Awa-Guajá peoples living in the protected area in question. This IT is located in the south of Maranhão, an area of 413 thousand hectares, with an estimated population of 13 thousand inhabitants (IBGE, 2012). In 2017, a territorial protection plan was prepared involving the State Coordination of the National Center for Forest Fire Prevention and Prevention (PREVFOGO) and the Environmental Education Center of the Brazilian Institute of Environment and Renewable Natural Resources (IBAMA) and several institutions: National Indian Foundation (FUNAI), National Institute of Colonization and Agrarian Reform (INCRA), Battalion Environmental Police (BPA), with local partnerships, such as: indigenous associations, rural unions, civil society and municipal governments. The objective was to sensitize indigenous and settlement community leaders with the formation of multipliers in the prevention and environmental education in the theme of burning and forest fires, encouraging the use of sustainable practices, conservation and sustainable use of natural resources and integrated fire management. The eight workshops took place in 2017 and 2018, involving 3 regions of TI Araribóia and its surrounding municipalities. 379 indigenous community leaders and land reform settlements participated. Participatory methodologies, group dynamics, spoken map, survey and visualization of problems and possible solutions were used from the construction of analysis and demonstration matrices for the implementation of agroforestry system. As already identified results, we have: elaboration of 41 action plans with themes related to the prevention and combat of forest fires, expansion of the articulation and communication between the involved institutions, increasing the level of effectiveness of the actions developed in the territory. Implementation of nurseries of forest species seedlings at TI Araribóia and planting in some spring areas. In addition to information received through informal reports from local residents about the decrease in fires in 2018.
\end{abstract}

Keywords: Indigenous people; settled; forest fires; methodologies participatory 